\title{
The Geophysical Observatory in Sodankylä, Finland - past and present
}

\author{
Tilmann Bösinger \\ University of Oulu, Oulu, Finland \\ Correspondence: Tilmann Bösinger (tilmannbsinger@gmail.com)
}

Received: 4 April 2021 - Accepted: 9 June 2021 - Published: 5 August 2021

\begin{abstract}
After a preface, we will first try to depict the history of the Geophysical Observatory in Sodankylä (SGO) by referring to the personalities who have run and have shaped the observatory. Thereafter, we describe the history from a technical point of view, i.e., what the measurements were, and which instruments were primarily used at the observatory. We will also refer to present operational forms and techniques.

We start with the very first systematic meteorological and geophysical observations made in Finland and end by referring to the involvement in ongoing international scientific programs.
\end{abstract}

\section{Preface}

Sodankylä (SOD) ${ }^{1}$ is a village located about $800 \mathrm{~km}(950 \mathrm{~km}$ by car) north of Helsinki, the capital of Finland. From the Arctic Circle, it is about $125 \mathrm{~km}$ northward to the village. It is embedded in the auroral belt.

Regular meteorological observations in Finland started in the middle of the 18th century at the Royal Academy of Turku. Observations were made by professors of the academy until the great fire of the city of Turku in 1827. After the fire, the academy was moved to Helsinki in 1828 and renamed the University of Helsinki.

Regular meteorological, and, additionally, geomagnetic visual observations, recorded in logbooks, started in Finland in 1838 when a magnetic and meteorological observatory was established at the University of Helsinki. It was implemented with the most modern equipment of its time. The measurements were made full-time, $24 \mathrm{~h}$ per day and $7 \mathrm{~d}$ a week, thanks to shift work by the observatory staff. In 1844, the observatory began its full-scale program. Its first director was Johan Jakob Nervander (1805-1848), a professor of physics (Simojoki, 1978; Holmberg and Nevanlinna, 2005).

Since the days of Nervander, meteorological, geomagnetic, and other related parameters have continuously been monitored and investigated in Finland. The observatory,

\footnotetext{
${ }^{1}$ The geographic coordinates of SOD (market square) are $67.24^{\prime} \mathrm{N}, 26.35^{\prime} \mathrm{E}$.
}

thereby, developed to the current Finnish Meteorological Institute (FMI; see below).

The University of Helsinki abandoned its magnetic observatory in 1881 , and the observatory was transferred to the management of the Finnish Society of Sciences and Letters $\left(\right.$ FSSL) ${ }^{2}$, which was established in 1838 . The priorities of the observatory changed from magnetism to meteorology, but magnetic measurements have continued up to today. Thus, Finland has an almost uninterrupted time series of changes in the country's magnetic field for the last 180 years. As an observation site, Sodankylä was included in meteorological measurements from 1858, after the FSSL launched a countrywide meteorological network in 1846.

Steady meteorological observations first began in 1908 in the village of Sodankylä and later, since 1914, continued at the Geophysical Observatory of Sodankylä (SGO), which is $6 \mathrm{~km}$ south of the village.

\footnotetext{
${ }^{2}$ The Finnish Society of Sciences and Letters (Suomen Tiedeseura) was founded in 1838. The Finnish Academy of Sciences and Letters (Suomalainen Tiedeakatemia) was founded in 1908. These were the leading scientific organizations in Finland in the 19th and early 20th centuries. The Academy of Finland (Suomen Akatemia) is a governmental research organization and was founded in 1947 and reorganized in the 1960s.
} 


\section{History}

\subsection{Sodankylä station during the First International Polar Year (1882-1883)}

The First International Polar Year (IPY) ${ }^{3}$ which was proposed by an Austro-Hungarian naval officer, Karl Weyprecht (1838-1881), in 1875 and organized by Georg Neumayer (1826-1919), the director of the German Maritime Observatory, pushed for a coordinated scientific approach to researching Arctic and Antarctic geophysical phenomena. Observers made coordinated geophysical measurements at multiple locations in both polar areas in 1882-1883, enabling multiple views of the same phenomena, which allowed a broader interpretation of the available data and a validation of the results. It took 7 years to organize the first IPY with 12 participating nations, including the Austro-Hungarian Empire, Germany, France, Denmark, Sweden, Finland (then part of Russia), the Netherlands, Norway, Russia, the United Kingdom, Canada, and the United States of America.

In 1881, during the International Polar Conference in St. Petersburg, Russia, the Finnish delegation, representing the FSSL and the Central Meteorological Institute in Helsinki, proclaimed that Finland would establish an observatory in Sodankylä as a remote station in northern Lapland for geomagnetic and meteorological measurements, together with observations of the northern lights. In addition, there were about 20 other different geophysical parameters to be observed. It incorporated about 750 single observations daily. The leading scientists in Finland during the IPY were physics professor Selim Lemström (1838-1904) and Ernst Biese (1856-1926), who was later the director of the Finnish Meteorological Institute (Simojoki, 1978).

The IPY activities in SOD were a decisive scientific achievement for Finland. It operated as a sovereign state, although at that time it could have operated under the leadership of Russia, as it was a Russian grand duchy ${ }^{4}$.

Demanding measurements were carried out under difficult conditions, according to the signed agreement. Shortly after the polar year, Lemström and Biese published their findings in three broad volumes. About 370000 observations had been accumulated. It was the first extensive study of the climate in Lapland and of certain geophysical properties in this area. It was a significant achievement in the history of the Finnish geoscience. The IPY activities in SOD were one of the largest and most expensive enterprises of Finland at times when it was an autonomous part of the Russian Empire (see Nevanlinna, 1999, 2004).

Lemström was a skilled organizer and received the necessary funds for the project from the Finnish government (senate), and an additional observational year was granted in

\footnotetext{
${ }^{3}$ The first IPY lasted 13 months, from 1 August 1882 to 1 September 1883.

${ }^{4}$ During Napoleonic times, Finland was annexed in 1800 and became part of the Russian Empire.
}

1884 on top of the IPY program. Moreover, Lemström had the foresight to market SOD's observational results in scientific journals (such as Nature) and in Finnish newspapers. Lemström's own peculiar theory of the northern lights as an electrical phenomenon of the atmosphere (Lemström, 1886; Holmberg, 1992) proved to be false, but, at times, it was well appreciated and accepted.

\subsection{The first years of the Sodankylä Geophysical Observatory}

In 1908, the Russian Academy of Sciences was going to join a global magnetic mapping program and suggested that Finland (FSSL; in practice it was directed to the Central Meteorological Institute) should carry out its own mapping independently. Gustaf Melander (1861-1938), director of the Central Meteorological Institute, responded to the task, and under his leadership, measurements began in 1910. Melander's plans were to require a permanent magnetic observatory in Lapland to support field measurements. The scientists within the FSSL were not enthusiastic about the project because they were afraid of too high costs, similar to those experienced during the IPY activities in SOD.

Melander solved the problem by assigning the observatory to the newly formed Finnish Academy of Sciences and Letters (FASL) in 1908. When private funding and extra state funds were received, the observatory project started. In the background was also Melander's effort to separate his institution, the Central Meteorological Institute, from the FSSL to form a state research institute. This was achieved, and in 1919, when the state Meteorological Central Institute was founded, it became a forerunner of the present-day Finnish Meteorological Institute (FMI).

Sodankylä was not immediately considered as a possible location; they also thought of Utsjoki, a village about $200 \mathrm{~km}$ to the north of SOD. Jaakko Keränen ${ }^{5}$ (1883-1979) magnetically examined, in 1910, the optional areas and concluded that the SOD's area, by the name of Tähtelä ${ }^{6}$, is magnetically not too anomalous. Keränen was trained as a magnetician in Potsdam, Germany, and, in 1913, was appointed as the first director of the Sodankylä Magnetic Observatory.

Originally, the observatory was solely a magnetic observatory, but Melander added meteorological observations to their full extent, and from 1 January 1914 onwards, SOD operated a first-class meteorological observatory of the FMI.

\footnotetext{
${ }^{5}$ Keränen was a meteorologist and a magnetician at the FMI from 1911 to 1919 and head of the institute from 1931 to 1953. Keränen published studies in the fields of meteorology and geomagnetism. Under the auspices of Keränen, a magnetic mapping of the Finnish territory was accomplished, making use of more than 1000 observation sites (Keränen, 1933).

${ }^{6}$ The campus of SGO is geographically located in a magnetically calm region called Halssinkangas. The name "Tähtelä" dates back to a local pun. Halssinkangas is a larger area than the actual site of SGO and Tähtelä.
} 


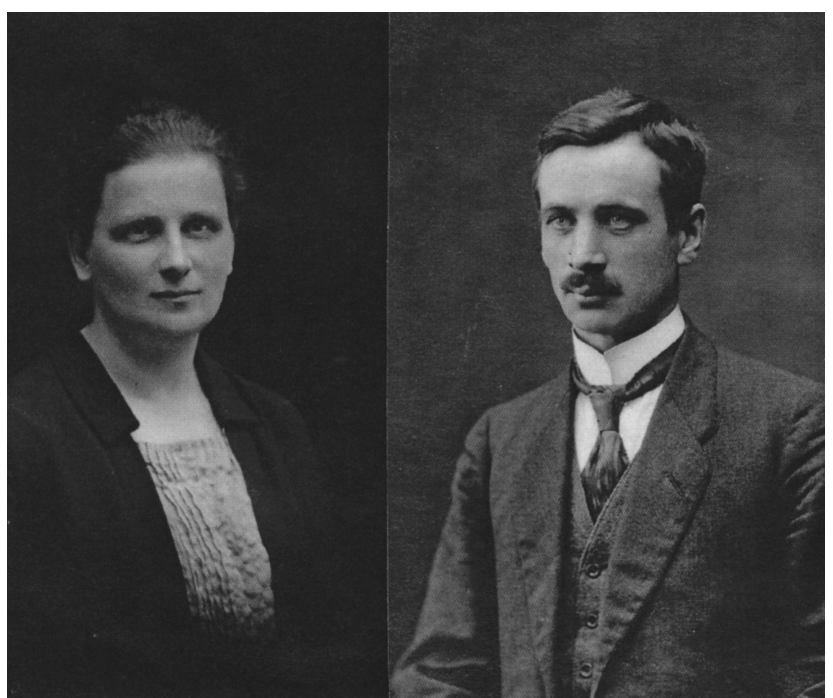

Figure 1. The couple, Siiri and Jaakko Keränen, photographed in around 1920. Jaakko was the first director of SGO, and Siiri was his assistant from 1913-1917. She made almost all the magnetic observations and edited the annual reports. In the summertime, Jaakko was absent because he was doing fieldwork; meanwhile, Siiri acted as his deputy director (photo supplied by FMI)

In the beginning, the staff of the observatory consisted of three people, i.e., the director Jaakko Keränen, his assistant, Siiri Pajari (1888-1968), who later became Keränen's spouse, and a janitor. Siiri took care of almost all magnetic observations and documentations and functioned as the observatory's head when her husband was absent while doing field work.

The First World War did not have much of an effect on the activities of the observatory, but little by little, the economic situation became worse. Finland was not self-sufficient in grain production and depended on imports from Russia, which ceased after the socialist revolution in Russia in 1917, causing growing inflation and countrywide starvation.

Daily measurements had to be interrupted temporarily. In 1917, Keränen left the observatory for a better paid position at the Finnish Geodetic Institute in Helsinki, and Heikki Lindfors (1894-1918) was elected as the deputy director of the observatory. The worst, however, was the effect of the civil war. The country was deeply divided into "Red" and "White" supporters, and the revolution, not unlike the October Revolution in Russia, aimed at leading to armed rebellions. Lindfors felt it was his duty to take part in the fighting on behalf of the White Army and was killed in action. After Lindfors's death, the activities at the observatory stopped for 3 months. In summer 1918, Keränen restarted magnetic registration. In early autumn 1918, Elias Levanto (1890-1965) was nominated as the new director (Simojoki, 1978). Levanto was in office for 3 years, and he was followed by Heikki Hyyryläinen from 1921 to 1927.

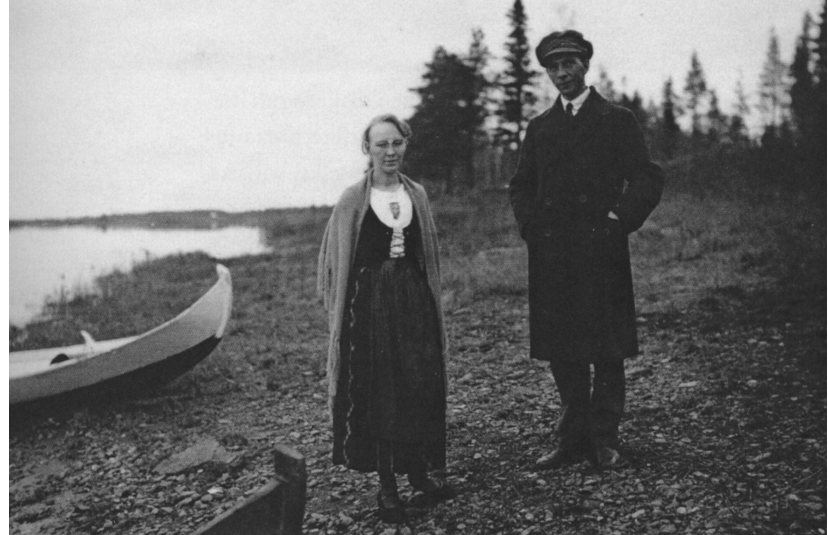

Figure 2. The couple, Annikki and Eyvind Sucksdorff, during the Second International Polar Year in 1932. The photo is taken at the site of the observatory on the shore of the river Kitinen. Annikki is wearing a traditional dress, and Eyvind is dressed in a local automobile club uniform. Sucksdorff headed the SGO between 1927 and 1945, and Annikki was his assistant. They had three children, all born in SOD (photo taken by Lyyli Takki and supplied by the Työväen Arkisto).

\subsection{Extension of the observational program under Eyvind Sucksdorff's directorship in 1927-1945}

The observatory committee of the FASL nominated Eyvind Sucksdorff $^{7}$ (1899-1955) as the director of the observatory in 1927. Up to this date, the observatory had been operated by four directors during 13 years. In those days, it was the only permanent magnetic and meteorological observatory north of the Arctic Circle. It had reached a prestigious position in the scientific community.

Sucksdorff's cooperation with Norwegian northern lights scientists (e.g., Carl Størmer; see Sect. 3.2) and Danish geomagneticians (including Dan la Cour) brought know-how to Sodankylä, in terms of developing northern light photography and photometry and magnetometers, as early as the late 1920s (La Cour and Sucksdorff, 1936). Functionally, the observatory, led by Sucksdorff, profited a lot from the experiences gained in Sodankylä through the association with the IPY program. Sucksdorff could use the large observational material collected in those years, including magnetic and meteorological observations, such as air electrical measurements and the northern lights. Due to these extensions of the observational program, in 1933 Sucksdorff proposed renaming the observatory the Sodankylä Geophysical Observatory instead of the Sodankylä Magnetic Observatory.

The Second International Polar Year (2nd IPY) in 19321933 meant additional activities for SGO because this is when it served as a training camp for IPY researchers making magnetic observations. Sucksdorff was able to cope with

\footnotetext{
${ }^{7}$ A recent comprehensive autobiography of Eyvind Sucksdorff was published in Finnish by Nevanlinna (2018).
} 
these new challenges and managed them skillfully with a few assistants. The most significant and long-term support for new tasks came through Sucksdorff's assistant, his wife Annikki (1904-1986), who, in many ways, participated in the observatory's demanding observations and statistical analyses of the measurements.

In parallel to the routine work of the observatory, Sucksdorff also worked as a creative researcher. He did pioneering work in the field of magnetic micro-pulsation (see Sect. 3.5), developed instruments for the measurements of magnetic variations (La Cour and Sucksdorff, 1936). His doctoral thesis was devoted to the periodicity of magnetic disturbances, which is called space weather today (Sucksdorff, 1942; Raita and Kultima, 2007). Sucksdorff laid the foundation for an entire research field, which later led to the formation of a national research community in the field of geomagnetic pulsations and magnetic disturbances. It gained international recognition and maintained international standards (Sucksdorff, 1947, 1952). It should, however, be noted, that Sucksdorff was not alone.

Around the same time, Leiv Harang, in Troms $\varnothing$, Norway, made similar studies of micro-pulsations (Harang, 1932, 1936; Sucksdorff, 1942; see the retrospective in Kangas et al., 2007).

The oldest routine task of the SGO was the regular measurement of the geomagnetic field. The measurements began on 1 January 1914 and continue until today. The only long gap in the time series is between 16 September 1944 and 1 January 1946 due to the destruction of the observatory. Towards the end of World War II, the German soldiers withdrew via Lapland to Norway, razing everything on their way, including the observatory. For a biography of Eyvind Sucksdorff, see Keränen (1956).

Sucksdorff left as the director of SGO in 1945. He joined the FMI as a magnetician. The main task after Sucksdorff's departure was to rebuild the observatory and to start the routine observations again. It was the job of two directors who followed in rapid succession, i.e., Maunu Seppänen (19011976; in office 1945-1947) and Tauno Hilpelä (1920-1952; in office 1947-1950), but Sucksdorff, in his new position as the first secretary of the FASL and observatory committee, did everything in his power to promote the project. In 1946, the continuous registration of geomagnetic variations could be restarted. The heads of the observatory committee, Jaakko Keränen and Vilho Väisälä (1891-1971), pushed forward the rebuilding of the SGO. They managed to gain the support of the FASL and received finally money from the government for new observatory buildings. The Meteorological Institute took responsibility for the meteorological functions and atmospheric sounding. Only the geomagnetic measurements were left to SGO. In this way, the Sodankylä Tähtelä campus was the operational base for two observatories from different organizations, i.e., the FASL for SGO and the FMI for Sodankylä Meteorological Observatory (Nevanlinna, 2014; Sucksdorff, 1952).

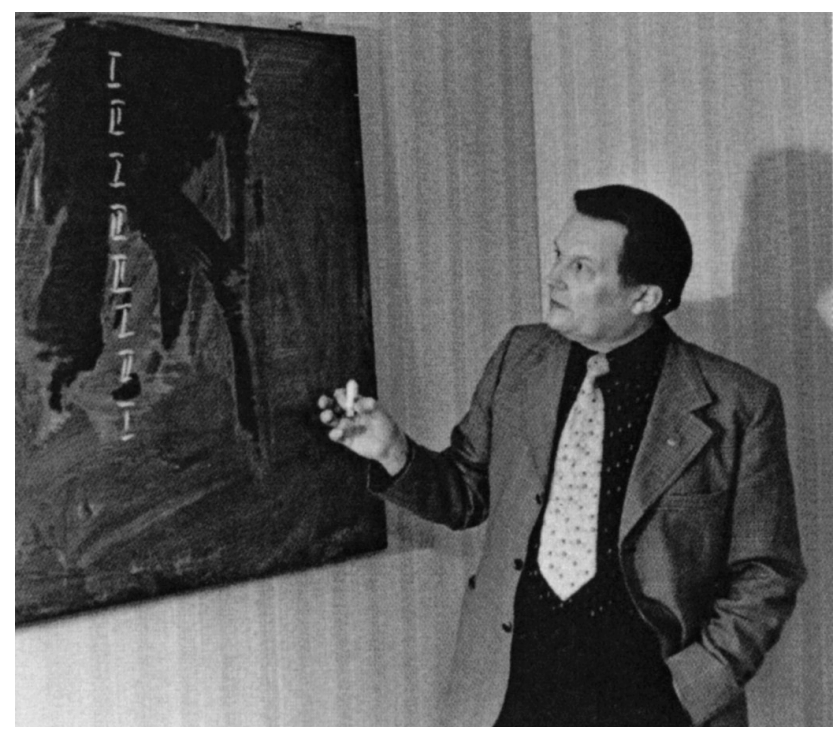

Figure 3. Eero Kataja lecturing at the Meteorological Observatory of Nurmijärvi in the 1970s (photo supplied by FMI).

\subsection{Development of the modern SGO under Eero Kataja's directorship (1950-1992)}

In 1950, the FASL nominated Eero Kataja ${ }^{8}$ (1927-2014) as the director of SGO, following Tauno Hilpelä. At the same time, Kataja's first wife, Hilkka Kataja, was chosen as a new staff member of the observatory. She served until 1955. Thereafter, Kataja's second wife (Airi Kataja; born in 1926) took the role of taking care of the seismic observations (1956-1991).

During Kataja's reign, the observatory developed from a decent observation site to a modern geomagnetic observatory comprising many branches of research activity and a multitude of modern measurement techniques. In Kataja's time, the staff of SGO increased significantly (5 to 10 times). Such a large institute required full-time staff and budget management, yet Kataja still found time to follow his own research interests (basically space climate and geomagnetic activity assessment by geomagnetic indices), to give lectures at the university, and to present reports in scientific meetings. He was an active member of the International Union of Geodesy and Geophysics (IUGG) and the International Association of Geomagnetism and Aeronomy (IAGA). Kataja was interested in magnetic indices in correlation with other geomagnetic parameters (Oksman and Kataja, 1981).

The International Geophysical Year (IGY) was an international scientific project that lasted from 1 July 1957 to 31 December 1958. It marked the end of a long period during the Cold War, during which scientific interchange between the East and West had been seriously interrupted. A total of 67

\footnotetext{
${ }^{8}$ Owing to his achievements at the observatory, the University of Helsinki awarded him an honorary doctorate in 1985 (Sucksdorff et al., 2001).
} 
countries participated in IGY projects, and East and West agreed to nominate the Belgian physicist and meteorologist Marcel Nicolet as the secretary general of the associated international organization.

The IGY encompassed the following 11 Earth sciences: aurora and airglow, cosmic rays, geomagnetism, gravity, ionospheric physics, longitude and latitude determinations (precession mapping), meteorology, oceanography, seismology, and solar activity. The timing of the IGY was particularly suited to the study of some of these phenomena, since it covered the peak of the solar cycle in 1958. Both the former Soviet Union and the USA launched artificial satellites for this event (Chapman, 1959).

SGO made big efforts in preparation for the IGY. In 1953, in close co-operation with FMI, the instruments for registering magnetic variations and their housing were already modernized to meet international standards. Auroral imaging was taken up, using Stoffregen cameras (see Sect. 3.2) constructed in FMI. Also, seismometers could be arranged and reinstalled, effectively shielding them from artificial disturbances. It should be stressed that SGO was not alone in preparing for IGY, and that it was the result of joint efforts of several Finnish institutions and universities.

Here, in the context of IGY and otherwise, many thanks go to Juhani Oksman (born in 1931). He pioneered the establishment of an ionospheric station and started ionospheric measurements and related research (more details below). With the additional ionospheric activities, SGO became again a real geophysical observatory. Funds for putting up buildings for the ionospheric station and for the staff were granted by the government, thanks to successful advertising and lobbying by Vilho Väisälä.

Since the 1960s, regular international seminars, workshops, and training programs have constituted an essential part of the observatory's life. The observatory has been and still is a favored place for scientists around the world to spend weeks, sometimes months, to work in solitude on some research topics in an inspiring community with competent collaborators. University doctoral programs are also offered and supervised at and by SGO.

\subsection{New host of SGO in 1997 and the new generation of directors}

In these years, SGO reached its full extent and by which it is widely known today. This is well underlined by the fact that, in 2001, the observatory's Tähtelä campus received a new main building ${ }^{9}$, with a modern lecture room, cafeteria, library, and plenty of offices for the FMI, as well as SGO staff. When Jorma Kangas acted as deputy director of the

\footnotetext{
${ }^{9}$ The building, called Polaria, a two-storied timber construction with large glass walls that offer views of the nearby forest and the river, is a marvel of modern wooden architecture. At the time, it was the largest public timber construction in Finland.
}

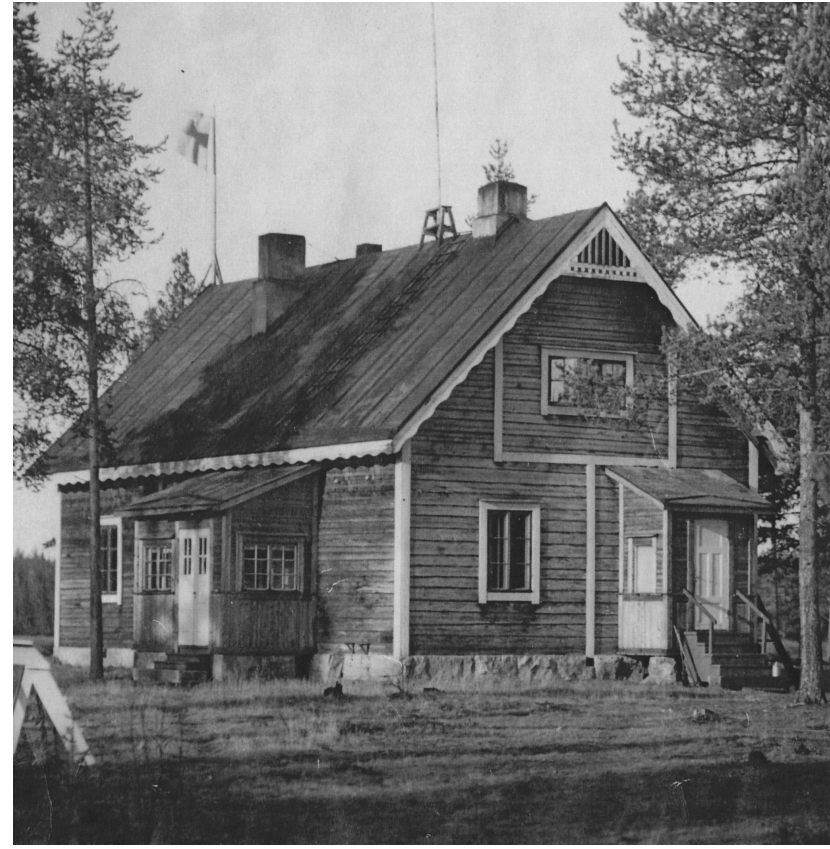

Figure 4. The main building of the Sodankylä Geophysical Observatory in around 1930 (photo supplied by FMI).

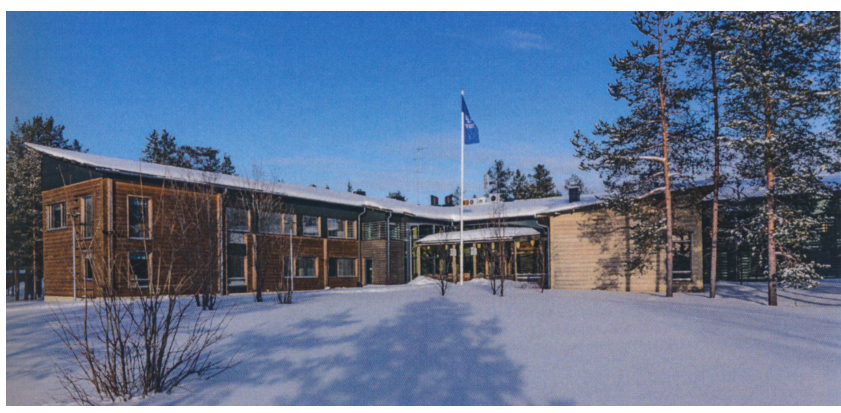

Figure 5. The joint main building - which goes by the name of Polaria - of the Sodankylä Geophysical Observatory and Lapland's Research Institute of the Finnish Meteorological Institute. The building was completed in 2001 (photo by Thomas Ulich).

Observatory in 1998-2002 (while on leave from the Department of Physical Sciences at the University of Oulu, UO), the observatory gained a lot from his worldwide connections in the scientific community and his wide experience in modern administrative management (as former deputy rector of the $\mathrm{UO}$ ).

After Kataja's term, Tauno Turunen was elected as the director of the Sodankylä Geophysical Observatory in 1992. He had studied at the University of Oulu, and he was keen to have closer connection with UO. Turunen's term as the director of the observatory in fact lasted 19 years, and he retired in 2011. While on leave from the observatory for 5 years, he acted as the director of EISCAT (European Incoherent Scatter Scientific Association; see Sect. 3.4 below). During 


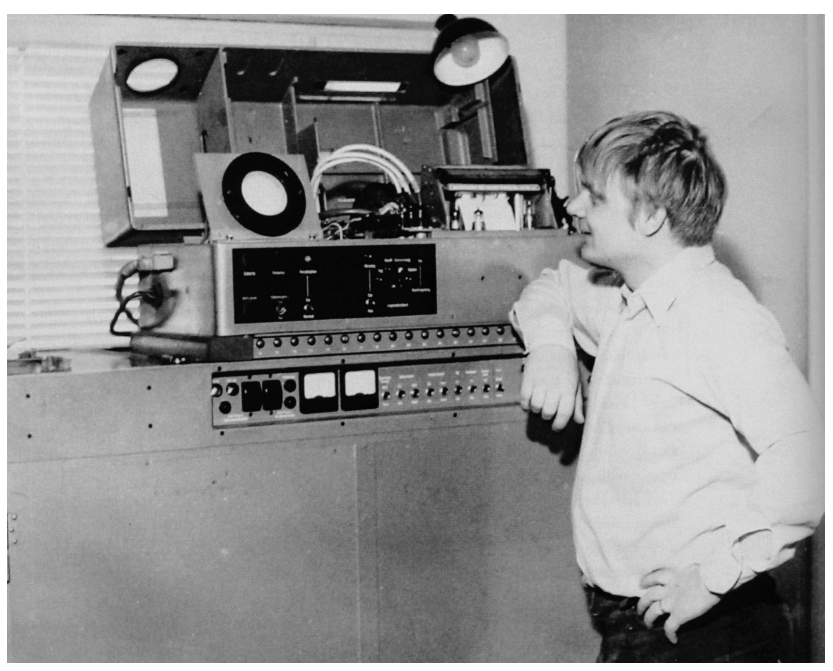

Figure 6. Tauno Turunen standing before the transmitter of the ionosonde in 1972 (photo supplied by SGO).

this time, Kangas, from the UO, acted as the deputy director of the observatory. Turunen is a gifted engineer and experimental physicist with a high intuition for problem solving. Thanks to him, there are several innovative improvements in observation techniques and instrumental development.

On 1 August 1997, the SGO became a research department of the University of Oulu (UO). Adding continuously new types of geophysical measurements on top of the research activities and ever-increasing international cooperation made it necessary to look for a new host. So far, the SGO had worked under the auspice of the FASL, and it was mainly financed by lottery funds via the Ministry of Education. To make longlasting planning possible and to ensure retirement funds for the observatory's employees, it was necessary to put the observatory legally and financially on a larger and more stable base of a state institution.

The most logical way to achieve this was to make the SGO a department of UO. For decades, there has already been close cooperation between SGO and UO in science and education. It intensified when, in the early 1980s, one of the remote receiving stations of the EISCAT radar was installed at SGO. It led to scientific cooperation between SGO and researchers in the EISCAT member states. The observatory and its outreach became, thereby, a strategic target for the University of the North and the Academy of Finland (AF), who were financing EISCAT.

In these years, research activities at the observatory became intensively occupied with ionospheric investigations by means of the EISCAT radars (see below; for clarity, EISCAT does not belong to SGO, but it is a European research institution, and the Finnish contribution is financed by the AF). At the same time, techniques for coding incoherent scatter radars and related data processing were developed in cooperation with the mathematicians of UO. In 2006, the AF se- lected this team, who were devoted to inversion problems, as being one of the centers of excellence in research. Markku Lehtinen from SGO has been a member of this team.

The observatory became incorporated in transnational European research projects, such as Europrobe (seismology and lithosphere) and FIRE (Finnish Reflection Experiment), in close contact with the Institute of Geoscience at the university. The long-term cosmic ray observations and recordings, which had been started at the Department of Physics in the 1960s (see below) and moved to SGO in 1998 received a new impetus by transforming the deep mine at Pyhäsalmi to a new observation platform.

Esa Turunen followed Tauno Turunen as the director of SGO in 2012, after a short interim period of having Jyrki Manninen and Thomas Ulich (2012-2013) as the deputy directors, respectively. Esa Turunen has also studied at UO and worked for many years at the observatory as a senior research associate. In parallel to supervising the ionospheric station, he worked with worldwide collaborators on an ionospheric D-region chemistry model, which is continuously being improved and updated and is widely used for, e.g., climate change surveys (e.g., Xu et al., 2018; Lee et al., 2021). In 2003, he became the director of the EISCAT scientific association (see Sect. 3.4 below).

After Esa Turunen's retirement in autumn 2019, Eija Tanskanen was elected as the new director of SGO. She has had the position of a visiting professor at Aalto University, Finland, while on leave from her position as professor at the University of Bergen. Tanskanen has extensive experience in research topics related to magnetic environment disorders and their mechanisms, including auroral substorms and solarmagnetosphere interactions.

In these later years, the SGO has grown to its current range of activities, which go far beyond traditional geophysical observatory duties, with more than 100 different observed geophysical parameters in more than 20 locations. It has been hosting international workshops, it has been the training site for doctoral students at various universities, and it is a favorite place for researchers to take their sabbaticals (research teams from institutions in the East and West spend weeks at SGO, concentrating on some joint projects in polar solitude, and they have the chance to enjoy Finnish saunas and the midnight sun at the Sodankylä Midnight Sun Film Festival).

\section{Observational programs and measuring devices}

\subsection{Magnetic observations}

SGO produced, almost uninterrupted for more than 100 years, measurements of the absolute Earth magnetic field and its secular variations. The measurement technique has subsequently been updated and always kept at an international standard. At the beginning, during Keränen's time, the magnetometer came from Germany. In Sucksdorff's time, around 1930, the instruments were the La Cour standard magne- 
tometers from Denmark, in parallel to quick-run $H, D$, and $Z$ variometers. Thanks to those, Sucksdorff observed for the first time, in parallel with (but independently of) Leiv Harang in Norway, micropulsations which are nowadays named Pc1 pearl magnetic pulsations (Sucksdorff, 1936; see Sect. 3.5 for more details) in quick-run La Cour magnetometer recordings. In 1956, SGO purchased a proton precession magnetometer, which facilitated, to a great deal, the measurement of the absolute magnetic field strength with high precision. The Carl Zeiss (Jena, Germany) DI instrumentation (i.e., non-magnetic theodolites with magnetometer sensor to observer declination and inclination) with a fluxgate magnetometer replaced multiple instruments (Askania product and a proton magnetometer with coil system) in the baseline control of the observatory in 1984. Since 1995, absolute field measurements have been carried out by means of a fluxgate magnetometer, and analogical photographic paper registration ended in December 1995. Measurement principals are described in the IAGA observatory manual by Jankowski and Sucksdorff (1996).

Digital continuous magnetic recordings started in around 1995. At the Technical University of Braunschweig, Germany, Hermann Lühr, built a magnetic digital magnetometer with magnetic cassette data storage and formed, in October 1982, with the support of SGO, a so-called EISCAT magnetometer cross, which covers a region in northern Fennoscandia (i.e., Pello, Muonio, Alta, Kautokeino, Sørøya, Kevo, Kilpisjärvi; cf. Lühr et al., 1984). In 1991, the network expanded with some new Finnish stations, and some old ones were closed. The new network was called IMAGE, the International Monitor of Auroral Geomagnetic Effects, and was managed and run entirely by $\mathrm{FMI}^{10}$. Later, other institutes and countries joined IMAGE, such as Estonia, Norway, and Sweden. SGO has continued to support FMI in the northern part of Finland. In 2018, the stations at Røst and Harestua joined IMAGE, totaling the number of stations to 41 and covering regions over the Baltic Sea. (cf. https://space.fmi.fi/MIRACLE/, last access: 18 March 2021; note that IMAGE is included in MIRACLE).

Even more synoptic power was achieved with MIRACLE (Magnetometers, Ionospheric Radars, All-sky Cameras Large Experiment). SGO also joined the global digital magnetometer network of INTERMAGNET.

SGO has also become a Europe-wide testing site for magnetometers under development and for calibration. In 2009, SGO hosted the 45th intercalibration campaign for northern countries (cf. Sucksdorff, 1939; Nevanlinna et al., 2011). In 2015, the novel automatic gyro DI (directional) instrument was tested at SOD and other semi-automatized DI instrument prototypes.

\footnotetext{
${ }^{10}$ October 1995 - FMI as the principal investigator (PI) institute; PI - Ari Viljanen; January 2010 - 12th IMAGE meeting (Bergen); new PI - Eija Tanskanen; June 2016 (new PI) - Liisa Juusola (FMI).
}

Although SGO was not directly involved, it should be mentioned in this context that the International Magnetospheric Studies (Roederer, 1976), with the involvement of the University of Münster, Germany, PI Jürgen Untiedt, operated a dense grid of magnetometers in northern Fennoscandia, namely the International Magnetospheric Study (IMS) Scandinavian Magnetometer Array (1976-1979; Untiedt and Baumjohann, 1993).

Today, SGO has taken responsibility for digitizing the registration films of the Scandinavian Magnetometer Array.

\subsection{Auroral observations}

Records of visual auroral observations, in conjunction with meteorological measurements, were carried out during the First Polar Year (1882-1884) and since then until the age of photographic assessment. This is true for most of the geophysical observatories of the Northern Hemisphere. Carl Størmer (1874-1957), a Norwegian scientist, was the first to use auroral photo cameras. He visited the SGO in 1927 and soon a cooperation with the Auroral Observatory in Troms $\varnothing$ was initiated. From autumn to spring 1928, a collection of 114 photos of auroral displays from three different locations (for triangulation) were obtained (cf. Nevanlinna, 2018). Later, with Størmer's cameras, thousands of auroral photos were taken and archived at SGO. The valuable material was lost when German troops destroyed all buildings of SGO in autumn 1944.

Modern, automatized auroral imaging got started in connection with the International Geophysical Year by FMI. A German-Swedish scientist, Wilhelm Stoffregen (19091987), developed an auroral camera, using a ball mirror with a camera mounted on top of it, that was high enough to not obscure too much of the field of view (Stoffregen, 1955). Photos were typically taken once per minute and stored on narrowband film. The films were developed and archived at FMI in Helsinki. At the beginning the pictures were in black and white, but later color positive films were used.

Along with progressing technical development, new types of instruments came into use, such as the photometer (MaxPlanck-Institut für Aeronomie - MPAE; e.g., Lange-Hesse and Lauche, 1977) and radio aurora receivers and multichannel scanning zenith photometers (UO). In 2000, in close cooperation with FMI, digital all-sky cameras came into use with intensified charge-coupled device (ICCD) image sensors, which will be replaced by color image cameras (the update started in 2020). From 2007 onwards, SGO and FMI made bistatic observations with narrowband filtered all-sky cameras with electron-multiplying charge-coupled device (EMCCD) image sensors. Since 2012, the station pair has been Abisko-Kilpisjärvi to support EISCAT observations. In tune with the Lapland Atmosphere-Biosphere Facility (LAPBIAT) program, SGO started with the University College 
London's interferometric observations ${ }^{11}$ in 2003 , which still is in operation. Since 2016, SGO has also hosted a $100 \mathrm{~Hz}$ EMCCD camera ${ }^{12}$ from the University of Nagoya, Japan, related to the Arase satellite.

The auroral observations were made, from the very beginning, simultaneously from different locations, and since 1970, the SGO network of auroral imaging has spanned from the southern tip of Finland (Nurmijärvi) up to northern Lapland (Kevo).

\subsection{The ionospheric station}

The so-called ionospheric station is very much connected with the name of Juhani Oksman. Among many new results, he observed the ionospheric signatures of a nuclear explosion in the former Soviet Union (Oksman and Kivinen, 1965). In parallel to ionosonde measurements, other remote measurements of ionospheric parameters were taken up, such as oblique, frequency sweep, radio wave sounding between Lindau, Germany (MPAE), and SGO, very low frequency (VLF) radio wave links over the polar cap from Seattle and Washington, USA, riometer and radio aurora observations and satellite signal Faraday rotation measurements. In all these years, the cooperation with MPAE (e.g., Dieminger, 1973; Dieminger et al., 1962; Möller and Tauriainen, 1975; Oksman et al., 1979), and various USA universities (Pennsylvania State University, etc.) were essential. Of equal importance was that SGO received, in 1962, a modern, solid main building equipped with modern facilities, a guest room, offices, library, sauna, etc., and a separate building for the ionospheric station. In later years, some radio astronomy activities of the University of Helsinki (Jaakko Tuominen and Jorma Riihimaa) spread to SGO, and it also built a receiving and command station for the first German scientific satellites (Azur and Aeros A and B), again in close cooperation with MPAE. In the 1960s and 1970s, the cooperation between SGO and MPAE was intensive, as witnessed by two more publications apart from those already mentioned (Hartmann and Tauriainen, 1973; Hartmann et al., 1977). After the transformation of the original MPAE into a Max Planck Institute for Solar System research in 1977, the cooperation weakened.

It would be interesting to portray the technical development by a series of ionosonde generations; here, we can

\footnotetext{
${ }^{11}$ The FPI (Fabry-Pérot interferometer; red line) was built up in autumn 2002, and the PI is Anasuya Aruliah (Aruliah et al., 2010). It was used for a tristatic measurement of the red emission at $250 \mathrm{~km}$ at the Kiruna and Skibotn stations. Since 2007, there has also been a color all-sky camera used in parallel to FPI, which helps the FPI to find good observations.

${ }^{12}$ The $100 \mathrm{~Hz}$ ISEE EMCCD camera was installed in September 2016. Parallel to it is a NIPR $10 \mathrm{~Hz}$ all-sky camera, which is related to the PWING project, where the camera's PI is Kazuo Shiokawa (http://www.isee.nagoya-u.ac.jp/dimr/PWING/en/, last access: 8 March 2021).
}

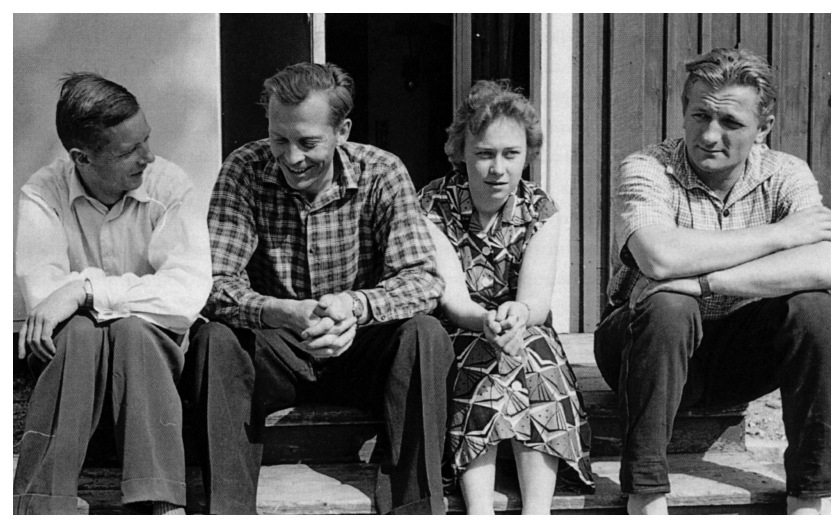

Figure 7. Hans-Georg Möller, Juhani Oksman, Mirja Martin (Hämäläinen), and Tarmo Mustonen in front of the ionospheric station (photo provided by Juhani Oksman).

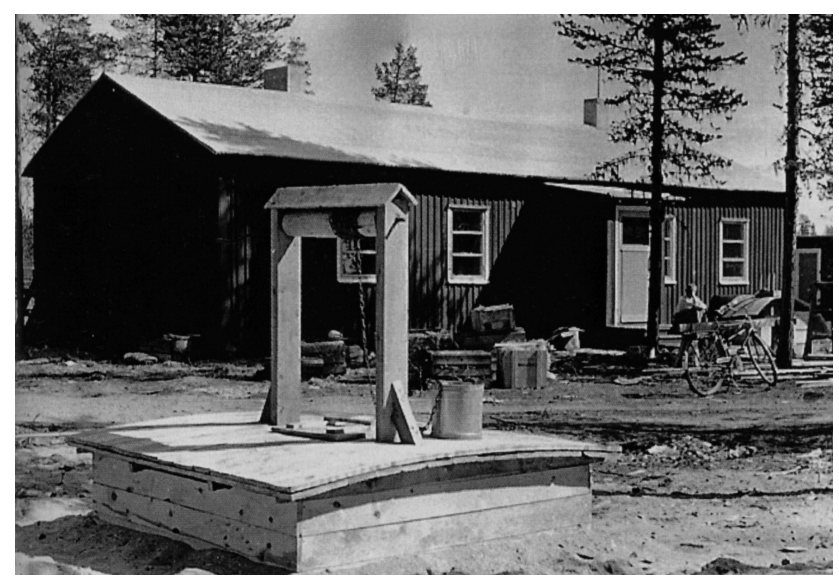

Figure 8. The ionospheric station with a well in the foreground (photo by Juhani Oksman).

only mention some highlights with relevance to SGO. The ionosonde is an ionospheric radar. It was already invented in the 20th century. The first ionosonde at SGO was a gift from Germany (Lindau, MPAE) in the 1950s. It was a robust vacuum-tube-based machine operating between 1 and $16 \mathrm{MHz}$ and had a transmission power of $10 \mathrm{~kW}$, with registration on films (cf. Oksman, 1963). It was in use for 20 years. The next generation was a design entirely by a Finnish consortium including SGO, UO, the Technical University of Helsinki, and the Finnish Post and Telecommunications company. Besides the power stage of the transmitter, it was entirely built on semiconductor technology. The device came into use in 1970. It turned out not to be reliable, until Tauno Turunen redesigned the instrument and its signal processing in 1978 (Fig. 6). The type of ionosonde in use today at SGO is of a completely different type. Here, Tauno Turunen chose a totally different approach. The receiver antenna array is separate from the transmitter, when, earlier, the same antenna was used for transmission and reception. 


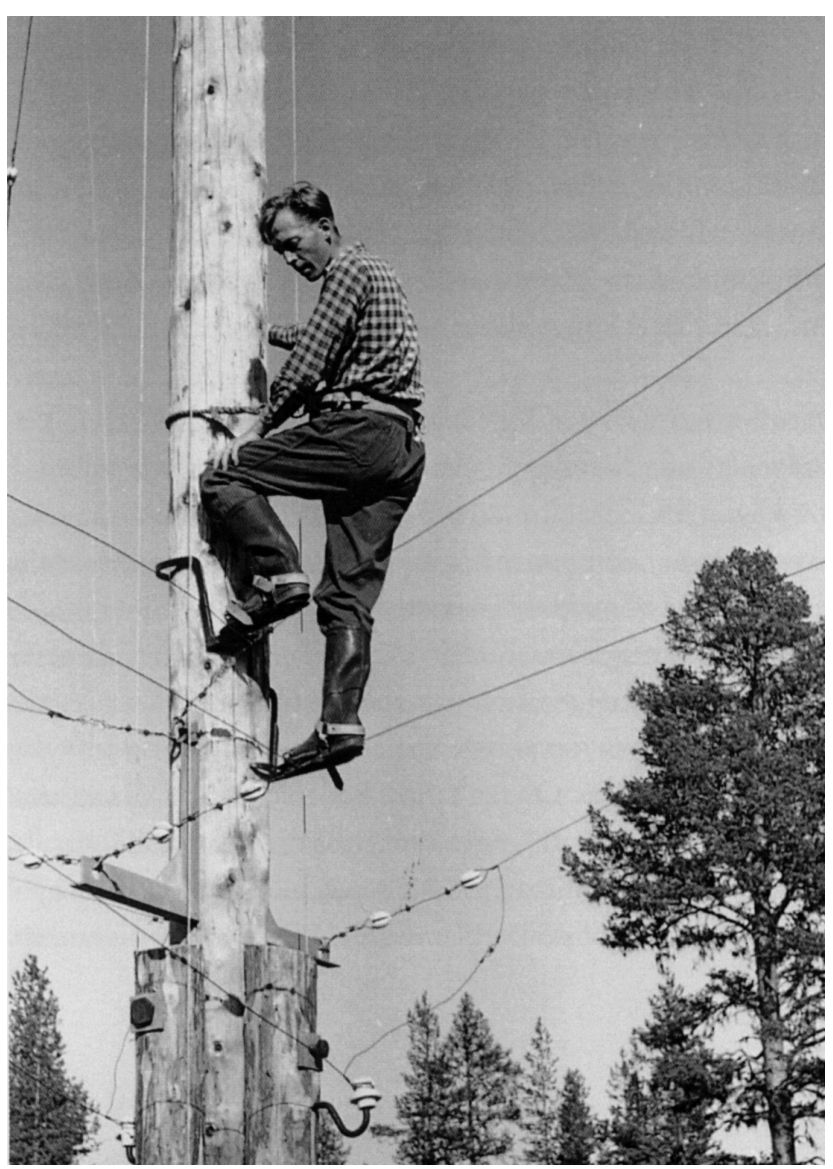

Figure 9. Juhani Oksman climbing up the antenna mast of the ionospheric station (photo provided by Juhani Oksman).

The Alpha Wolf ionosonde is transmitting a sweeping continuous signal, with a linear frequency shift from $500 \mathrm{kHz}$ till $16 \mathrm{MHz}$, where allocated frequencies are omitted. The transmission power is below $10 \mathrm{~W}$, and the time delay (travel time) between transmitted signal and received echoes is inferred from the frequency difference between the related signals. The ionosonde is capable of doing soundings once per minute, whereas earlier soundings were done every 30 and 15 min during specially selected days (cf. Kozlovsky, 2013).

\subsection{Pulsation magnetometer}

A decisive discovery was made at SGO long before specific pulsation magnetometers were designed. It was due to a resonance in the system of La Cour magnetometers which made them overly sensitive in a frequency range of around $1 \mathrm{~Hz}$. Eyvind Sucksdorff (see above) observed and published observations of periodic magnetic variations, which are nowadays known as Pc1 pearl pulsations. As a matter of fact, similar observations were independently reported by Leiv Harang from the Troms $\varnothing$ Auroral Observatory (Harang, 1936). He called these pulsations "vibrations"; the term "pearls" stems

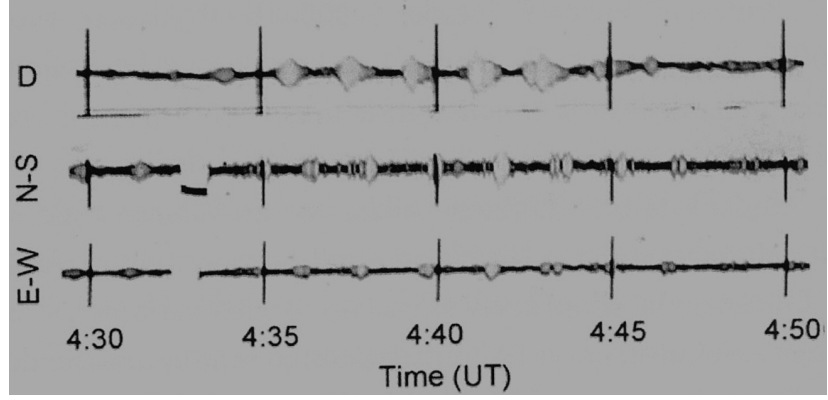

Figure 10. Geomagnetic pulsation registered at SGO on 6 February 1935 . Especially in the $D$ component, the repetitive occurrence of pearls are discernible, which gave rise to the term Pc1 pearl geomagnetic pulsations (see Kangas and Raita, 2017).

from Sucksdorff and is due to the specific appearance in the fast run La Cour registrations. Also, Matti Kivinen (19242012) from FMI, contributed to this field.

It took many decades before research in magnetic pulsations really started. It is due to contacts between Victor P. Hessler from Alaska University and Finnish scientists, especially Jorma Kangas from the University of Oulu. At the beginning of the 1970s, magnetic pulsation had become its own research field and was strongly advocated by a research team of the University of Oulu (Mursula et al., 1991; Kangas et al., 1998) in close operation with SGO and research institutes in the East and West (i.e., Valerie Troitskaya, 19172010; Victor Trakhtengerts, 1939-2007; Anatoly Guglielmi; Victor Hessler, 1903-1997; Richard Heacock, 1916-2020; and John Olson, among others; where not already otherwise mentioned, cf., e.g., Kangas et al. , 1998; Trakhtengerts et al., 2000). International projects, such as the International Magnetospheric Studies (1977-1979) and the first Swedish scientific satellite program (1984-1985), boosted activities. Around 1975, the pulsation magnetometer network consisted of five stations spanning from the southern tip of Finland up to the northernmost border.

The pulsation magnetometers were of the search coil magnetometer type. The first search coil sensors were bought in Japan; later, they were ordered from the Geophysical Observatory of the University of Göttingen, and the latest version was built at the workshop of the Physics Department of the University of Oulu (Waterman, 1981). The instruments have been updated several times, and digital data are available from the SGO archive web page (https://www.sgo.fi/Data/ Pulsation/pulArchive.php, last access: 8 March 2021). Today, one can admire near-real-time spectrograms of the Finnish chain of pulsation magnetometers from eight stations covering signals up to $35 \mathrm{~Hz}$, including Schumann resonances.

\subsection{Riometer}

In 1961, MPAE, Lindau, started riometer observations (cosmic noise absorption). Later, SGO received some riometers 
from MPAE (Schwentek and Gruschwitz, 1970). They were put in operation along a meridian chain with one station at SGO. In 1980, the instruments were modernized from David Anderson riometers to La Jolla riometers, and in 1987, five riometers from the University of Leicester were put under the auspices of SGO. In 1994, a new type of a multibeam riometer IRIS (imaging riometer for ionospheric studies) was installed at Kilpisjärvi (northwestern Lapland). Hilkka Ranta (1940-1996), a researcher from SGO, devoted all her successful scientific work to this kind of ionospheric sounding (see, e.g., Ranta and Ranta, 1977; Ranta et al., 1981; Novikov et al., 1980).

The La Jolla riometers have produced long time series from many sites. These single frequency and narrowband receivers with wide-beam antennas are retiring. A novel instrumental type of spectral riometer (multifrequency and two polarization) has been developed at SGO in the commercial collaboration division.

\subsection{VLF (very low frequency) measurements}

The history of VLF observations at SGO is a real success story. The activities in this field started late, in 1972, and as a kind of hobby. Tauno Turunen built a mobile VLF receiving station to be carried along in a rucksack. A long wire served as the antenna, and the RF (radio frequency) signal was recorded on a $c$ cassette recorder. A total of 10 years of observations with this primitive device revealed astonishing VLF effects, yielding a publication in Nature (Turunen et al., 1980). Strong worldwide AM radio transmissions triggered, modified, or mixed extremely low frequency (ELF) and VLF signals. The hunt was on. The next VLF receiver built by Turunen was already more of a professional type. The antenna consisted of six solenoids, each with an effective cross section of $126 \mathrm{~m}^{2}$. A triplet of crossed paired solenoids, each of them placed at some distance from each other, formed a 3D signal reception. Registration was made digitally on six channels for short times and on a video recorder for longer time periods.

Because of the strong omega navigation transmission signals, the VLF observations were restricted to $0.2-10 \mathrm{kHz}$. Hopes of being able to receive the VLF signal of the former Soviet Union's Aktivnyi satellite were in vain because the satellite's antenna did not deploy properly.

A decisive innovation in the forthcoming development was due to a suggestion by Turunen's student Jyrki Manninen. His idea was to combine auroral, magnetic and VLF signals simultaneously on the same media (Manninen, 2005). This was possible by means of a video recorder. The auroral image of a camera was stored on the video channel, and the stereo audio channels were used for the VLF signal. The internal clock of the video recorder guarantees exact timing. The ULF (ultra-low frequency) signal of the pulsation magnetometer could be superimposed on the video signal without too much disturbance, due to its ULF (Manninen, 2005).
International cooperation is also a must in VLF research (cf. Nunn, 1999). After 2000, there have still been two more generations of VLF antenna designs, VLF receivers and digital registration units, and online data transfer. Everything is now computerized, and this implies modern techniques of data processing. It is impossible to mention all the technicians and scientists who were involved in these projects. Although the research field was opened late at SGO, already some 80 scientific articles have been published as a result of the work done there. The unique VLF data provided material for several MS and doctoral theses and allowed the continuation of fruitful cooperation with several research institutes in Russia, which had started already in the time of the former Soviet Union.

Since 2002, SGO has also participated to the global VLF receiver networks of AARRDDVARK and AWDA with its own receiver development. AARRDDVARK continuously monitors the propagation paths of VLF transmitters, and AWDA is an automatic whistler detector (see Lichtenberger et al., 2008).

\subsection{European Incoherent Scatter (EISCAT) facility}

A European Incoherent Scatter facility in the auroral zone was a big joint research enterprise between Sweden, Norway, Finland, Germany, France, and the United Kingdom. The initiative was started by Bengt Hultqvist from the Kiruna Geophysical Observatory and the Swedish Space Institute in Kiruna. The enterprise's first constitutive meeting was held in Kiruna on 20 January 1976, and the first measurements were made in July 1981 (Hultqvist, 2011).

The three static radar systems meant that there were large parabolic receiving antennas located in Troms $\varnothing$, Kiruna, and Sodankylä (SGO) and two transmitters (UHF - 931 MHZ and $1-2 \mathrm{MW}$; VHF - $221 \mathrm{MHz}$ and $1.5 \mathrm{MW}$ ) located in Troms $\varnothing$ (see Fig. 14). It was a great challenge in many respects - technically, operationally, and scientifically. It yielded totally new radar coding and decoding schemes (Tauno Turunen and Markku Lehtinen), and SGO played an essential role in all those and not only as a host of one of the receiving stations. Although the financial contribution to EISCAT from Finland (e.g., the Academy of Finland) was the smallest among all EISCAT member states, the technical and scientific results (publications) from Finland were most significant. Thanks to a grant from the Academy of Finland to Juhani Oksman, on leave from his position as professor of the technical faculty of UO, he served as an EISCAT research assistant during the critical years of building up the whole EISCAT system and putting it into operation (1976-1981). A detailed documentation thereof can be found in Oksman (2011). The 3G mobile networks demanded the UHF (ultra-high frequency) band, and the Sodankylä station was adopted to the VHF (very high frequency) band. The planned EISCAT-3D phase array will replace the old radar system (https://eiscat.se/eiscat3d-information/, last ac- 

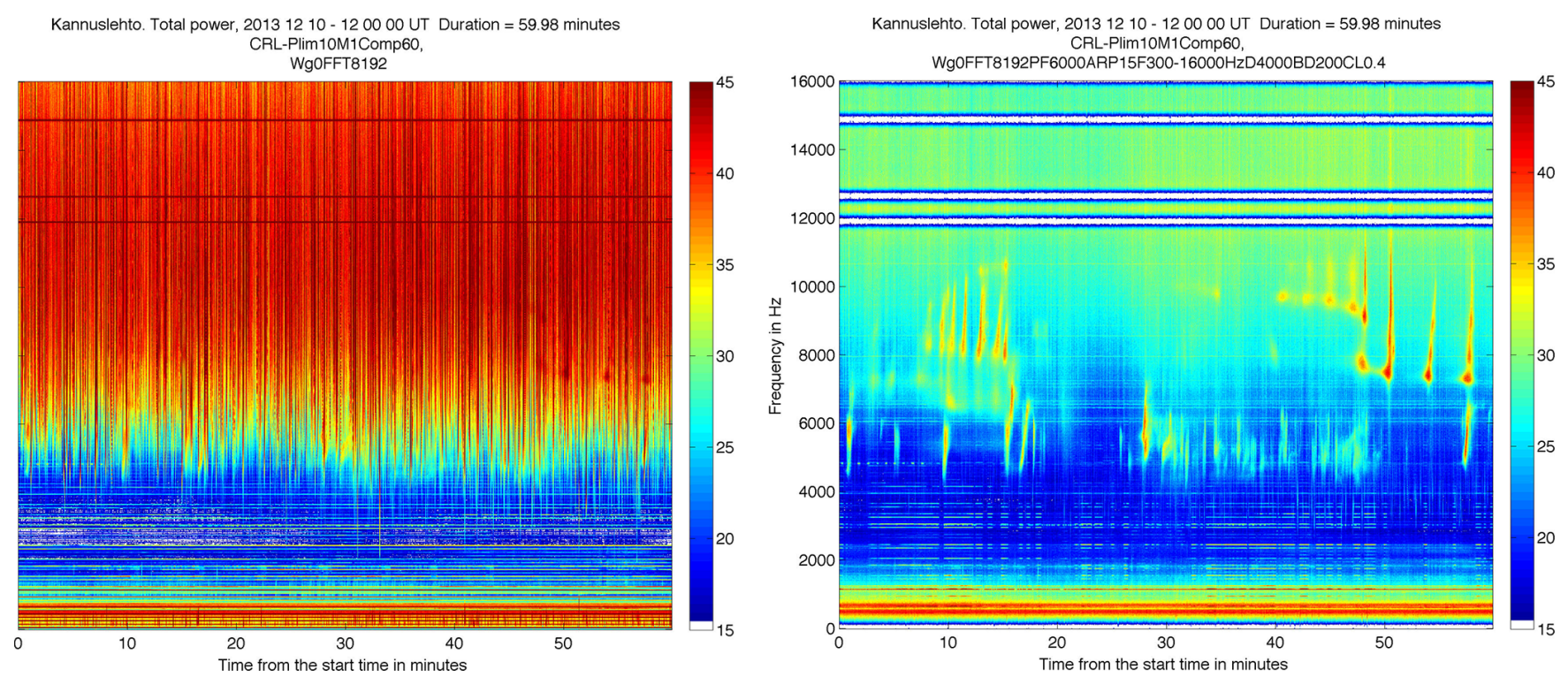

Figure 11. (a) A dynamic spectrum (frequency versus time with color-coded intensity) of VLF observations between 0 and $16 \mathrm{kHz}$. Above $5 \mathrm{kHz}$, worldwide lightning activity covers the whole spectrum. This is very typical for ground-based VLF observations. (b) The same spectrum with a lightning stroke suppression filter applied, thereby new types of VLF emissions become visible (figures by Jyrki Manninen).

cess: 20 February 2021). The new stations will be in Skibotn (Norway), Karesuvanto (Finland), and Kajseniemi (Sweden). The University of Oulu and SGO are strongly involved in the building of the Karesuvanto site. The list of publications stemming from EISCAT investigations would fill a whole book. Here is one citation - pars pro toto - where investigators from SGO, UO, and the Institute of Applied Physics from Nizhny Novgorod, Russia, were involved. It is a good example of where the fields of auroral physics and magnetic pulsations made use of the new tool provided by EISCAT (Bösinger et al., 1996).

Apart from the EISCAT VHF and ULF transmitter and receiver site in Troms $\varnothing$, there has been a powerful RF transmitter in operation for the artificial heating of the lower ionosphere and related research. The transmitter was initially built and operated by MPAE but was later transferred to the EISCAT association. Over many years, SGO was annually involved in so-called heating experiments (e.g., Bösinger et al., 2000; Kero et al., 2000).

A pathfinder for technologies used in the proposed EISCAT 3D radar system is a new type of riometer called KAIRA (Kilpisjärvi Atmospheric Imaging Receiver Array). It is a project of SGO, and it is a dual array of omnidirectional VHF radio antennas. It makes extensive use of the proven LOFAR (low frequency array) antenna and digital signal processing hardware and can act as either a standalone passive receiver, as a receiver for the EISCAT VHF incoherent scatter radar in Troms $\varnothing$, or for use in conjunction with other Fennoscandian VHF experiments (PI Antti Kero, project head, Markku Lehtinen).

\subsection{Seismometer}

The first trial of seismic observations at SGO dates to 1954. It was due to an initiative of the University of Helsinki (Eijo Vesanen, 1912-2005). Support came also from the University of Uppsala (Markus Båth, 1916-2000). The instrument was of the Benioff type (Benioff, 1932). In the early years, finding a proper site caused difficulties. Parasitic disturbances near the observatory made it senseless to continue. Finally, a suitable place was found in Pittiövaara, $12 \mathrm{~km}$ from SGO, where a remote observation platform of various kinds of geophysical parameters was set up. Also, the University of Oulu became involved in building up an entire network of seismic observations (Mauno Porkka, born in 1927). In the beginning, the registrations were made on photographic paper. Airi Kataja (see above) oversaw the interpretation and categorization of the seismograms before they were forwarded to the universities of Helsinki and Oulu. Worth mentioning here are the records of an earthquake close to the coastline of Alaska in 1964 , with $9.2 \mathrm{M}_{\mathrm{L}}$ and the $50 \mathrm{Mt}$ nuclear blast of the former Soviet Union over Novaya Zemlya on 30 October 1961. Its seismic signatures at SGO yielded a publication in Nature (Rose et al., 1961).

From 1980 onwards the focus shifted to deep seismic sounding and lithosphere research. In 2000, the instruments were upgraded and modernized and also included short period registrations. The data storage was made in line with international standards and led to an agreement with the Deutsches GeoForschungsZentrum (GFZ - German Research Centre for Geosciences) in Potsdam, Germany, concerning archiving and dissemination. The SGO seismic network was extended in the 2010 s by a few more broadband 


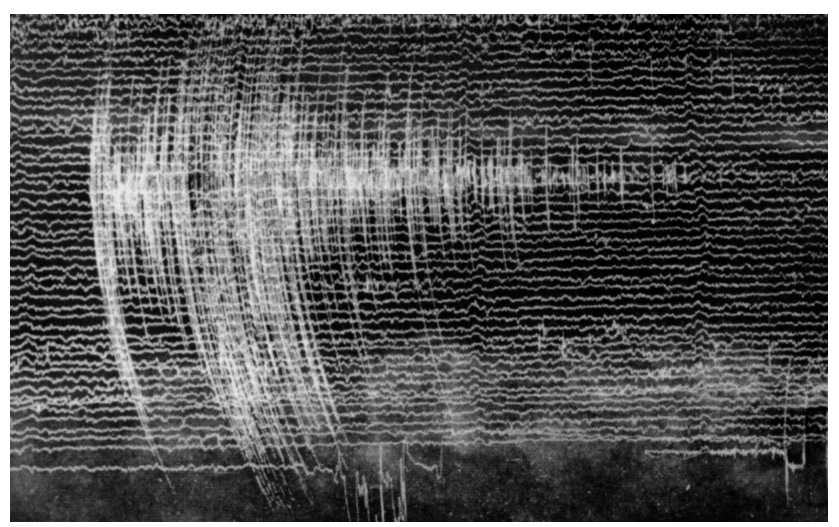

Figure 12. Seismogram registered at the site of Myllytulli, Oulu, witnessing an earthquake that took place in Hautajärvi, Salla, northeastern Finland, on 20 February 1960 (photo supplied by Heikki Korhonen).

seismic stations, with the first borehole seismic station in Finland. Also, temporal network instrumentation was purchased in cooperation with the Oulu Mining School.

Internationalization of the research field is best depicted by a number of abbreviations standing for the following projects in which Finnish seismologists have participated: EPOS (European Plate Observing System), SVEKA'81 and SVEKA'91 (Finland, Poland, the former Soviet Union, Sweden, and Germany; deep seismic sounding), BALTIC, FENNIA (Baltic and Bothnian echoes from the lithosphere), ROPROBE/SVEKALAPKO (seismic tomography, incorporating 14 universities), CELEBRATION 2000 (Central European lithospheric experiment based on refraction 2000), and POLENET/LAPLET (polar Earth observing network) joint with the International Polar Year (2007-2009).

Nowadays, the University of Oulu holds a professorship (Elena Kozlovskaya) in mineralogy and prospecting and is hosting an applied seismological laboratory (SEISLAB) in close cooperation with the mining industry (e.g., Pyhäsalmi Mine).

\subsection{A zenith telescope}

The observatory had a permanent position for an astronomer. An initiative to measure the polar motion of the Earth at SGO, i.e., the motion of the Earth's rotational axis with respect to Earth's crust, is due to the mathematician and geodesist Ernst Bonsdorff (1842-1936), Gustaf Melander (see Sect. 1.2), former chief of the Meteorological Institute in Helsinki, Jaakko Keränen (see above), and Yrjö Väisälä. The project was supported by the International Polar Motion Service in Japan (International Earth Rotation and Reference Systems Service - IERS) and many other international agencies. Yrjö Väisälä built several zenith telescopes $(250 / 5000 \mathrm{~mm})$, and one was given to SGO. He himself was not able to take part in the measurements; this was given, af- ter some interim solutions, to the astronomer Johannes Kultima (1945-2014), a student of Yrjö Väisälä. A total of six stars were chosen for routine (day and night) measurements, and the most prominent was the Delta Draconis in the Draco constellation. Measurements were made from 1973 to 1987 , when the accuracy of satellite measurements started to exceed those of ground-based measurements.

\subsection{Stratospheric balloon measurements}

It was originally a project of the Department of Physics of the University of Oulu (Pekka Tanskanen and Jorma Kangas). It was initiated by Jean-Pierre Legrand from the Laboratoire de Physique Cosmique in Meudon, Paris. In the 1960s and 1970s, it grew to an international consortium under SPARMO (Solar Particles and Radiation Monitoring Organization), incorporating the abovementioned French institute, MPAE in Lindau, the University of Bergen in Norway, the Alfvén Laboratory, KTH Royal Institute of Technology in Stockholm, Sweden, the Geophysical Observatory of Kiruna in Sweden, the Technical University of Graz in Austria, the Danish Space Research Institute in Lyngby, Denmark, and the University of California, Berkeley in the USA (Forrest Mozer).

The aim was to measure the effects (e.g., Röntgen radiation, even of electric fields) of high-energy solar particles penetrating the upper atmosphere, in conjunction with solar proton events and magnetospheric substorm. In the summer months between 1965-1979, altogether more than 70 balloons were sent up to the stratosphere with their scientific payload from different sites in northern Europe. The role of SGO was to provide logistical and technical help and human effort during the campaigns and to offer suitable launch sites.

\subsection{Cosmic rays' monitors}

The newly founded University of Oulu (1959) started with a few institutes, and one was the Department of Physics. In 1962, it was decided that one research field would be cosmic rays. The first step (Pekka Tanskanen) was to build a meson telescope (it measures the hard component of cosmic rays). The instrument worked up to 1966 when it became necessary to build a new telescope functioning not with Geiger-Müller tubes but rather with plastic scintillation cubes. The scintillations were detected by photomultiplier tubes.

In 1962, a neutron monitor was also built. It allowed the registering of high-energy particles (mainly protons, neutrons, and $\alpha$ particles) coming from space (Tanskanen, 1965). It was done (Sauli Niemi and Hannu Kananen) in cooperation with the Canadian Nuclear Laboratory in Chalk River (Hugh Carmichael). This monitor is still working and belongs, along with the monitor in Apatity, Russia, to the oldest instruments of its kind that provides a long-term record of solar activity and cosmic rays. The activities were entirely initiated and guided by the staff of the Department of Physics, 

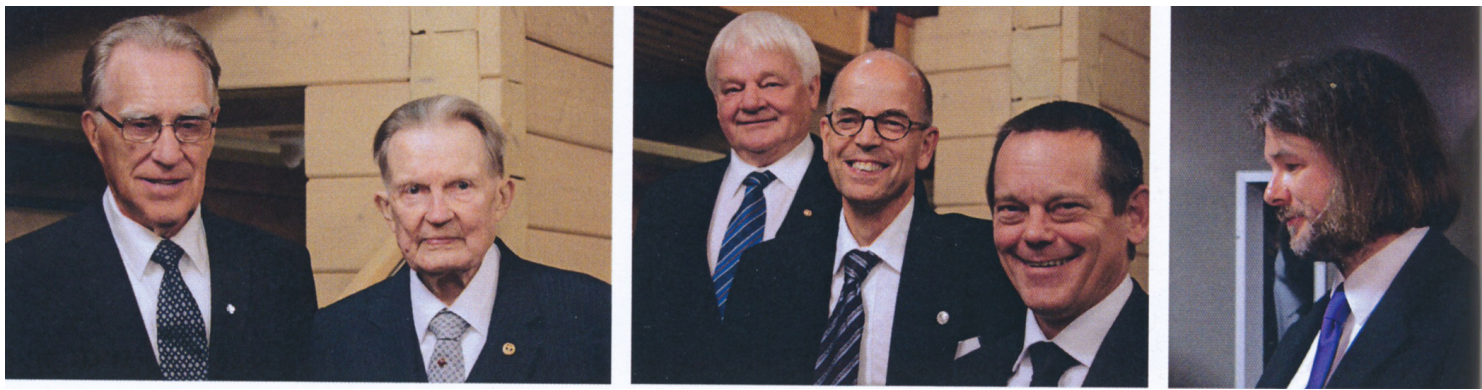

Figure 13. At the festivities of the 100th anniversary of SGO in 2013, where five directors of the observatory (past and present) met. From left to right: Jorma Kangas and Eero Kataya, Tauno Turunen, Esa Turunen, and, on the far right, Thomas Ulich, followed by Craig Heinselman, who was the director of EISCAT at that time (photo supplied by SGO).

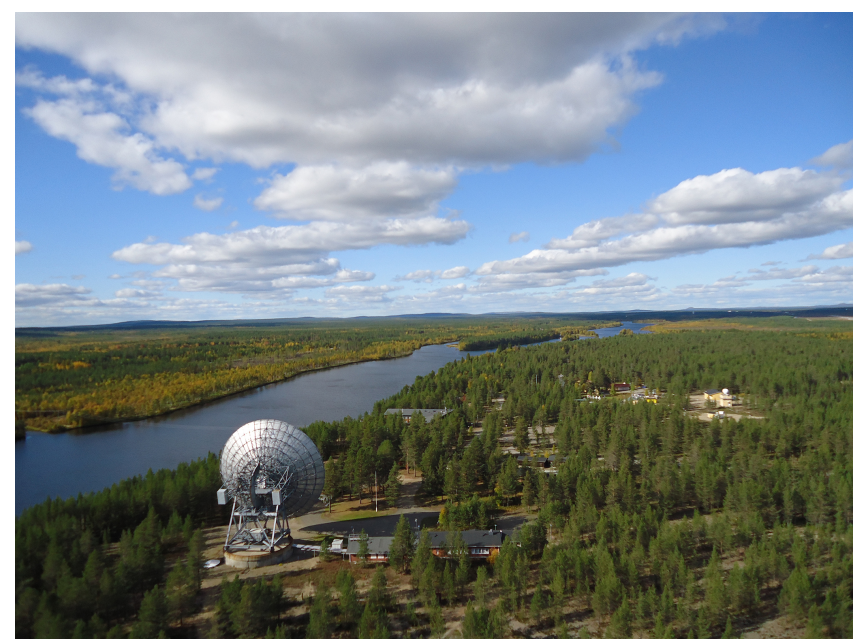

Figure 14. The Sodankylä Geophysical Observatory, the Meteorological Research Institute of Lapland, the buildings belonging to the EISCAT compound and the EISCAT antenna in the front, SGO's buildings further down, and the river Kitinen is shown on the lefthand side (photo by Timo Rantala).

but since SGO today belongs to the University of Oulu, the project should also be mentioned in this history. In the 1970s and 1980s, the cosmic ray station was run by Hannu Kananen. During the last 20 years, Ilya Usoskin oversaw the station, and he is an internationally well-known expert in cosmic ray physics.

\subsection{Workshop}

The technical workshop is the soul of an observatory. Especially in Lapland, in the far north, where there is little industry around and no downtown shops for special technical items, the ability to be able "do it yourself" is persistent. No wonder that at the end of last century one could find caretakers, carpenters, painters, technicians, engineers, and radio and computer experts among other specialists at the work- shop. And the workshop also had its own building and operates its own laboratory.

But, it all started from nothing. At the beginning, the staff of the observatory consisted only of three persons, namely the director, an assistant, and a caretaker (see above). At the workshop, the modernization of most of the observatory's measuring devices and associated data storage and data transfer systems has taken place. Also, fluxgate magnetometers for rocket flights and satellite missions were built there in cooperation with Cornell University, USA. In addition, new types of geophysical observations were included in the observatory's program, such as the SLICE meteor radar (Leicester University) and a satellite receiving and control station (ISIS-I and ISIS-II), which always go hand in hand with new challenges for the workshop.

A good illustration of the technical development from 1945 up to 2000 is a summary of the time standards which were in use at SGO, including the Rohde and Schwarz quartz clock, the Finnish radio broadcast time signal, the EISCAT system Caesium clock, LORAN radio signal phase lock clock, the German DCF77 longwave radio time signals, and, finally, the global GPS-clock network.

The greatest challenge of an observatory is guaranteeing permanent registration over many decades for geophysical parameters and, thereby, following international standards. On the one hand, one must be aware of technical developments; on the other hand, one must keep an eye on maintaining the specific class or nature of the geophysical observation so that the data are comparable with data from the distant past (conservative approach).

A geophysical observatory always implies (from the very beginning) cooperation with international institutions (see above). Frequent national and international measuring campaigns (e.g., balloons, EISCAT, VLF, aurora, ionospheric HF (high frequency) heating, and satellites) made it necessary for the staff of the workshop to temporally take part, in one way or the other, in these activities and often around the clock. Many names could be mentioned. Here, we recall only a few: Hans-Georg Möller (MPAE), Juhani Oksman 
(see above), Aarne Ranta, Tarmo Mustonen, Pekka Vilkki, Markku Postila, and Timo Rantala.

\section{Outreach}

Also worth mentioning here are cooperation agreements between the bodies of the former Soviet Union and the Foreign Ministry of Finland. This cooperation turned out to be very fruitful and has continued between SGO and the Polar Geophysical Institute in Apatity, the University of Nizhny Novgorod, and the Institute of Physics of the Earth in Moscow from the late 1970s up to today. On the other side was an agreement between NSF (National Science Foundation, USA) and the Academy of Finland (study of ionospheric and magnetospheric phenomena in the auroral zone). A total of six workshops were held between 1981 and 1997 on either side of the Atlantic, and a key figure in the promotion of US-Finnish joint scientific activities was Walter Heikkila (University of Texas at Dallas).

It is difficult to do justice to everyone and to be precise about the details within a short paper. Below are some remarks and abbreviations which give an impression of the outreach of SGO. The routine meteorological measurements from 1908 onwards and the records of atmospheric sounding from 1949 onwards belong, worldwide, to the longest existing continuous time series of its kind made north of the Arctic Circle. Also, regular measurements of the geomagnetic filed and its secular variation since 1914, the records of geomagnetic pulsations since the early 1930s, spanning many solar cycles, are outstanding. Furthermore, projects such as the Finland FUVIIRC project (Finland International Research Centre), LAPBIAT and LABIAT2 (Lapland Atmosphere Biosphere Facility), Thule Institute (University of Oulu), IHP-program (Improving Human Potential) are worth noting. The ever-increasing usage of remote sensing by space probes made the Sodankylä branch of FMI, officially called LIT (Lapin Ilmantieteellinen tutkimuskeskus - Lapland's meteorological research center) and today the Arctic Space Centre of the FMI, a central satellite receiving and control center with wide range applications beyond mere meteorological purposes. In 2018, FMI and the University of Oulu (UO) agreed to increase space activities and intensify cooperation on the Sodankylä Space Campus, which houses the Arctic Space Centre of the FMI with SGO as part of UO.

The spirit of SGO is best depicted by the long tradition of annual Observatory Days held at SGO, which are, from time to time, combined with various national and international workshops.

\section{SGO and Sodankylä}

Sodankylä is a municipality in the region of Lapland (the northernmost part of Finland) and is located some $125 \mathrm{~km}$ north of the Artic Circle. It has a population of about 8200 in- habitants, and it is also the home of a Finnish Defense Force's garrison, the Jaeger Brigade. The municipality has two official languages, namely Finnish and Northern Sámi. Sodankylä is well known to many tourists fond of Artic nature in midst of what was called the last European wilderness. It also has international prestige for its Midnight Sun Film Festival.

SGO has been an important employer for the municipality and has added to the international flavor of the municipality owing to the frequently visiting scientists and students at SGO from all over the world. The cooperation between the municipal authorities and the observatory has been always stimulating and innovative. This is best documented by a recently formed initiative of Arctic players in Fennoscandia, called the Center for Artic Geoinovations (CAGI), 2016, where SGO, besides other institutions, has a central responsibility.

\section{Closing remarks}

The maintenance and continuous improvement of observatory operation at SGO over many generations in challenging northern conditions and irrespective of national catastrophes are among the most important contributions of Finland to geoscience.

This paper is a paraphrased summary of the book published in Finnish in celebration of the 100th anniversary of the Sodankylä Geophysical Observatory 2013 (edited by Nevanlinna, 2017).

Data availability. No data sets were used in this article.

Competing interests. The author declares that there is no conflict of interest.

Disclaimer. Publisher's note: Copernicus Publications remains neutral with regard to jurisdictional claims in published maps and institutional affiliations.

Special issue statement. This article is part of the special issue "History of geophysical institutes and observatories". It is not associated with a conference.

Acknowledgements. For critical reading, important additions, and corrections, the author thanks Heikki Nevanlinna (FMI), Jorma Kangas, Jyrki Manninen, and Tero Raita (SGO/UO). The author remembers, with many thanks, the staff and colleagues of SGO from numerous visits in the context of the Observatory Days, international workshops, and regular meetings with research teams from East and West. 
Review statement. This paper was edited by Kristian Schlegel and reviewed by two anonymous referees.

\section{References}

Aruliah, A. L., Griffin, E. M., Yiu, H.-C. I., McWhirter, I., and Charalambous, A.: SCANDI - an all-sky Doppler imager for studies of thermospheric spatial structure, Ann. Geophys., 28, 549-567, https://doi.org/10.5194/angeo-28-549-2010, 2010.

Benioff, H.: A new vertical seismograph, B. Seismol. Soc. Am., 22, 155-169, 1932.

Bösinger, T., Kaila, K., Rasinkangas, R., Pollari, P, Kangas, J., Trakhtengerts, V., Demekhov, A., and Turunen, T.: An EISCAT study of a pulsating auroral arc: simultaneous ionospheric electron density, auroral luminosity and magnetic field pulsation, J. Atmos. Sol-Terr. Phys., 58, 23-35, 1996.

Bösinger, T., Pashin, T., Kero, A., Pollari, P, Belyaev, P., Rietveld, M., Turunen, T., and Kangas, J.: Generation of artificial magnetic pulsations in the Pc1 frequency range by periodic heating of the Earth's ionosphere: indications of ionospheric Alfvén resonator effects, J. Atmos. Sol-Terr. Phys., 62, 277-297, 2000.

Chapman, S.: IGY - Year of discovery: the story of the international geophysical year, University of Michigan Press, Ann Arbor, 1959.

Dieminger, W.: 20 years of cooperation in ionospheric research with Finland, Veröffentlichungen des geophysikalischen Observatoriums der Finnischen Akademie der Wissenschaften, 56, 59-72, 1973.

Dieminger, W., Oksman, J., and Rose, G.: Ionospheric D-region phenomena associated with auroral disturbances at Sodankylä, J. Atmos. Terr. Phys, 24, 823-824, 1962.

Harang, L.: Observations of micropulsations in the magnetic records at Troms $\emptyset$, J. Geophys. Res., 37, 57-61, 1932.

Harang, L.: Oscillations and vibrations in magnetic records at high latitude stations, J. Geophys. Res., 41, 329-336, 1936.

Hartmann, G. K. and Tauriainen, A.: Negative Horizontale Gradienten des integralen Elektroneninhalts in der Ionosphäre, Kleinheubacher Berichte, 16, 259, 1973.

Hartmann, G. K., Leitinger, R., Degenhardt, W., Hedberg, A., Oksman, J., and Tauriainen, A.: Zur Dynamik des polaren F-SchichtTroges, Kleinheubacher Berichte, 20, 117-127, 1977.

Holmberg, P.: The History of Physics in Finland 1828-1918, The History of Learning and Science in Finland 1828-1918, Societas Scientiarum Fennica, Helsinki, 267 pp., 1992.

Holmberg, P. and Nevanlinna, H.: Geomagnetism in Finland: the lasting legacy of Johan Jakob Nervander, Europhysics News, 3, $82-85,2005$.

Hultqvist, B.: History of EISCAT - Part 1: On the early history of EISCAT with special reference to the Swedish part of it, Hist. Geo Space. Sci., 2, 115-121, https://doi.org/10.5194/hgss-2-1152011, 2011.

Jankowski, J. and Sucksdorff, C: Guide for magnetic measurements and observatory practice, IAGA, Warsow, 235 pp., 1996.

Kangas, J., Guglielmi, A. ,and Pokhotelov, O.: Morphology and physics of short-period magnetic pulsations, Space Sci. Rev., 83, 435-512, 1998.

Kangas, J., Fraser, B., and Potapov, A. (Eds.): Pc1 pearl waves: Discovery, morphology, and physics, J. Atmos. Sol.-Terr. Phys., 69, 1599-1774, 2007.
Keränen, J.: A magnetic survey of Finland on July 1, 1930, Finn. Met. Inst. Stud. Earth Magn., 17, 39 pp., 1933.

Keränen, J.: Gustaf Eyvind Sucksdorff 1899-1955, Geophysica, 5, 58-62, 1956.

Kero, A., Bösinger, T., Pollari, P., Turunen, E., and Rietveld, M.: First EISCAT measurement of electron-gas temperature in the artificially heated D-region ionosphere, Ann. Geophys., 18, 1210 1215, https://doi.org/10.1007/s00585-000-1210-8, 2000.

Koskinen, H.: Geophysics in Finland in the twentieth century, Space Phys. Geophys., 37, 309-355, 2001.

Kozlovsky, A., Turunen T., and Ulich, T.: Rapid-run ionosonde observations of traveling ionospheric disturbances in the auroral ionosphere, J. Geophys. Res.-Space, 118, 5265-5276, https://doi.org/10.1002/jgra.50474, 2013.

La Cour, D. and Sucksdorff, E.: Exemple d'emploi du QHM pour contrôle des variométres pour la déclinaison et pour la force horizontale, Publikationer Det Danske Meteorologiske Institut, 16, 1-11, 1936.

Lange-Hesse, G. and Lauche, H.: Detection of ionospheric irregularities by ground-based optical methods, Kleinheubacher Berichte, 20, 105-116, 1977.

Lichtenberger, J. C., Ferencz, L., Bodnar, D., Hamar, and Steinbach, P.: Automatic Whistler Detector and Analyzer system: Automatic Whistler Detector, J. Geophys. Res., 113, A12201, https://doi.org/10.1029/2008JA013467, 2008.

Lee, J.-H., Jee, G., Kwak, Y.-S., Hwang, H., Seppälä, A., Song, I.-S., Turunen, E., and Lee, D.-Y.: Polar Middle Atmospheric Responses to Medium Energy Electron (MEE) Precipitation Using Numerical Model Simulations, Atmosphere, 12, 133, https://doi.org/10.3390/atmos12020133, 2021.

Lemström, S.: L'aurore Boreale, Gauthier-Villars, Paris, 199 pp. 1886.

Lühr, H., Thürey, S., and Klöcker, N.: The EISCAT-Magnetometer Cross, Geophys. Surv., 6, 306-315, 1984.

Manninen, J.: Some aspects of ELF-VLF emissions in geophysical research, Doctoral dissertation, Oulu University Press, 2005.

Mursula, K., Kangas, J., Pikkarainen, T., and Kivinen, M: Pc 1 Micropulsations at a high-latitude station: A study over nearly four solar cycles, J. Geophys. Res., 96, 17651-17661, https://doi.org/10.1029/91JA01374, 1991.

Möller, H. G. and Tauriainen, A.: Observations of intense irregularities in the polar F-region by HF backscatter and satellite scintillation measurements, J. Atmos. Terr. Phys., 37, 161-167, https://doi.org/10.1016/0021-9169(75)90098-7, 1975.

Nevanlinna, H.: Geomagnetic observations at Sodankylä during the first international polar year (1882-1883), Geophysica, 35, 1522, 1999.

Nevanlinna, H.: Results of the Helsinki magnetic observatory 1844-1912, Ann. Geophys., 22, 1691-1704, https://doi.org/10.5194/angeo-22-1691-2004, 2004.

Nevanlinna, H., Häkkinen, L., and Raita, T.: Geomagnetic activity at the Sodankylä observatory, 1914-2010, Geophysica, 47, 3142, 2011.

Nevanlinna, H.: On the early history of the Finnish Meteorological Institute, Hist. Geo Space. Sci., 5, 75-80, https://doi.org/10.5194/hgss-5-75-2014, 2014.

Nevanlinna, H. (Ed.): Sodankylän geofysiikan observatorio 19132013 - sata vuotta havaintoja ja tutkimusta, Sodankylä Geophysical Observatory Publications No. 112, 2017. 
Nevanlinna, H.: Geofyysikko Eyvind Sucksdorff - havaintojen taituri, Suomen Tiedeseura, ISBN: 978-951-653-424-7, ISSN: 0067-8481 Oy Grano Ab, 65100 Vasa, 2018.

Novikov, Y. P., Kopytenko, Y. A., Raspopov, O. M., Bösinger, T., Kangas, J., and Ranta, H.: Simultaneous Maxima of Geomagnetic Pulsations and Riometer Absorption on the Afternoon Side of the Auroral Zone, J. Geophys., 48, 116-120, 1980.

Nunn, D., Manninen, J., Turunen, T., Trakhtengerts, V., and Erokhin, N.: On the nonlinear triggering of VLF emissions by power line harmonic radiation, Ann. Geophys., 17, 79-94, https://doi.org/10.1007/s00585-999-0079-4, 1999.

Oksman J.: Studies on the Auroral Sporadic E Ionization at Sodankylä, Ann. Acad. Sci. Fenn. A, 1963, 58 pp., 1963.

Oksman J.: History of EISCAT - Part 2: The early history of EISCAT in Finland, Hist. Geo Space. Sci., 2, 123-128, https://doi.org/10.5194/hgss-2-123-2011, 2011.

Oksman J. and Kataja E.: IMF polarity and annual variations of the Dst index, Geophys. J. Int., 65, 603-609, 1981.

Oksman, J. and Kivinen, M.: Ionospheric gravity waves caused by nuclear explosions, Geophysica, 9, 119-128, 1965.

Oksman, J., Möller, H. G., and Greenwald, R.: Comparisons between strong HF backscatter and VHF radar aurora, Radio Sci., 14, 1121-1133, https://doi.org/10.1029/RS014i006p01121, 1979.

Raita, T. and Kultima, J.: Discovery of the pearl waves by Eyvind Sucksdorff, J. Atm. Sol.-Terr. Phys., 69, 1600-1603, 2007.

Ranta, H. and Ranta, A.: Daily variation of absorption in the $D$ region using riometer data at high latitudes, J. Atmos. Terr. Phys., 39, 309-312, 1977.

Ranta, H., Ranta, A., Collis, P. N., and Hargreaves, J. K.: Development of the auroral absorption substorm: Studies of preonset phase and sharp onset using an extensive riometer network, Planet. Space Sci., 29, 1287-1313, 1981.

Roederer, J. G.: IMS 1976-1979: New Concepts in International Scientific Cooperation, EOS, 57, 6-8, https://doi.org/10.1029/EO057i001p00006, 1976.

Rose, G., Oksman, J., and Kataja, E.: Round-the-World Sound Waves Produced by Nuclear Explosion on October 30, 1961, and Their Effects on the Ionosphere at Sodankylä, Nature, 192, 11731174, 1961.

Schwentek, H. and Gruschwitz, E. H.: Measurement of absorption in the ionosphere on $27.6 \mathrm{MHz}$ at $52^{\circ} \mathrm{N}$ by means of a riometer and a corner reflector antenna directed to the Pole star, J. Atmos. Terr. Phys., 32, 1385-1402, https://doi.org/10.1016/00219169(70)90100-5, 1970.
Simojoki, H.: The history of geophysics in Finland 1828-1918, The History of Learning and Science in Finland 1828-1918 - Societas Scientiarum Fennica, Helsinki, 157 pp., 1978.

Stoffregen, W.: All-Sky Camera Auroral Research during the Third Geophysical Year 1957-58, Tellus, 7, 509-517, 1955.

Sucksdorff, E.: Occurrences of rapid micropulsations at Sodankylä during 1932 to 1935, Terrestrial Magnetism and Atmospheric Electricity, 41, 337-344, 1936.

Sucksdorff, E.: Giant pulsations recorded at Sodankylä during 1914-1938, Terrestrial Magnetism and Atmospheric Electricity, 44, 157-170, 1939.

Sucksdorff, E.: Die erdmagnetische Aktivität in Sodankylä in den Jahren 1914-1934, Veröffentlichungen des geophysikalischen Observatoriums der Finnischen Akademie der Wissenschaften No. 25, Sanan Valta, 68 pp., 1942.

Sucksdorff, E.: Diurnal variations of computed electric currents in the high atmosphere, Terrestrial Magnetism and Atmospheric Electricity, 52, 201-215, 1947.

Sucksdorff, E.: The geophysical observatory Sodankylä, Geophysica, 5, 17-47, 1952.

Sucksdorff, C., Bösinger, T., Kangas, J., Mursula, K., Nygrén, T., Kauristie, K., and Koskinen, H.: Geophysics in Finland in the twentieth century - Space Physics, Geophysica, 37, 309-355, 2001.

Tanskanen, P. J.: On the variation of cosmic ray meson intensity at sea level in connection with atmospheric disturbances, Ann. Acad. Sci. Fenn. Ser. A VI Phys., 185, 1965.

Turunen, T., Cannon, P. S., and Rycroft, M. J.: ELF radio signals in the auroral ionosphere generated by non-linear demodulation of LF and/or MF transmissions, Nature, 286, 375-377, https://doi.org/10.1038/286375a0, 1980.

Trakhtengerts, V. Y., Belyaev, P. P., Polyakov, S. V., Demekhov, A. G., and Bösinger, T.: Excitation of Alfvén waves and vortices in the ionosphere by modulated powerful radio waves, J. Atmos. Sol.-Terr. Phys., 62, 267-276, https://doi.org/10.1016/S13646826(99)00121-2, 2000.

Untiedt, J. and Baumjohann, W.: Studies of Polar Current Systems Using the IMS Scandinavian Magnetometer Array, Space Sci. Rev., 63, 245-390, 1993.

Watermann, J.: Theory of Induction Magnetometers with High Permeable Cores, Geophysical Institute, University of Göttingen, English summary of his Diplomarbeit in German, 1981.

Xu, W., Marshall, R. A., Fang, X., Turunen, E., and Kero, A.: On the effects of bremsstrahlung radiation during energetic electron precipitation, Geophys. Res. Lett., 45, 1167-1176, 2018. 